\title{
FUNÇÃO E CAMPO DO RECALQUE E DO LUTO NO CONTEXTO DA CULTURA: REFLEXÕES SOBRE O RACISMO, O BANZO E O BLUES
}

\author{
Nilda Martins SiRelli; Denise Maurano
}

Nilda Martins Sirelli

Universidade Estácio de Sá (Unesa), Professora da Faculdade de Psicologia, Macaé/RJ, Brasil.

\section{Denise Maurano}

Universidade Federal do Estado do Rio de Janeiro (UNIRIO), Professora Associada do Programa de PósGraduação em Memória Social, Rio de Janeiro/RJ, Brasil.
Resumo: 0 presente artigo parte da concepção de memória na psicanálise freudiana, visando discutir a dialética lembrança-esquecimento mais especificamente no contexto da cultura. Desdobraremos a complexidade dos mecanismos presentes no esquecimento a partir da noção de recalque, e ainda averiguaremos a singular relação entre o esquecimento e o trabalho de luto, para daí depreender suas consequências tanto para o sujeito quanto para a cultura. Os efeitos da operação do recalcamento serão avaliados em alguns fenômenos da cultura, como o racismo, o banzo e, em contrapartida, a invenção do blues, como resultado da operação de luto, possibilitando a criação.

Palavras-chave: recalque; racismo; luto; criação; blues.

Abstract: Function and field stresses and mourning in the context of culture: reflections on racism, the flange and the blues. This article is part of the memory concept in Freudian psychoanalysis, in order to discuss the memoryoblivion dialectic more specifically in the context of culture. It discusses the complexity of the mechanisms present in oblivion from the notion of repression, and investigates further the unique relationship between forgetting and grief work to then infer its consequences for the individual, and for the culture. The effects of repression of the operation will be evaluated in some culture phenomena such as racism, the flange and, on the other hand, the invention of the blues as a result of grief operation, enabling the creation.

Keywords: repression; racism; mourning; creation; blues.

DOI - http://dx.doi.org/10.1590/S1516-14982018002002

Todo o conteúdo deste periódico, exceto onde estiver identificado, está licenciado sob uma Licença Creative Commons (cc by 4.0) 


\section{INTRODUÇÃO}

O presente artigo parte da concepção de memória na psicanálise freudiana, visando discutir a dialética lembrança-esquecimento no contexto da cultura. Para tal, vamos nos deter sobre as diversas nuances da questão: o que é esquecimento? Esquecimento é igual a deixar de saber? E, logo, como contrapartida, lembrar é ter disponível a consciência um determinado saber, um conhecimento? A partir da teoria freudiana, podemos desdobrar a complexidade da questão do esquecimento a partir da noção de recalque, e ainda averiguar a singular relação entre o esquecimento e o luto, para daí depreender suas consequências, tanto para o sujeito quanto para a cultura.

A psicologia, e mesmo o senso comum, designa como esquecido o material que não está à disposição da consciência em determinado momento. $O$ conceito de recalque subverte essa lógica, pois o material recalcado permanece inacessível à consciência, mas vivo na memória.

Nas palavras de Freud, a essência do recalque "consiste apenas em rejeitar e manter afastada da consciência" (FREUD, 1915/2010, p. 85) determinada representação. Assim, o recalque apenas indica que o representante não chega à consciência, mas continua a produzir efeitos no inconsciente, organiza-se ainda mais, gerando os derivados ou substitutos do recalcado. Esses, sim, chegam à consciência presentificando o recalcado, contudo, no desconhecimento. Há um não saber, mas não um esquecimento, pois o conteúdo continua sendo atualizado em ato, produzindo os mais diversos efeitos de retorno, seja pela via do sintoma, do ato falho, do sonho ou do chiste.

A esse processo de repúdio ao material inconsciente, Freud (1919/2010) destaca o caráter de estranhamento suscitado pelas formações inconscientes: o sujeito não se reconhece naquilo que the é mais familiar e constituinte, e que vem revelar seu posicionamento nas mais diversas relações e na vida. Toda entrada no discurso daquilo que é recalcado pode abalar a unidade imaginária do Eu, pois traz algo da alteridade íntima que nos habita. O recalcado é, então, constitutivo de uma memória inconsciente, seu conteúdo é latente, oculto à consciência, não manifesto. Memória latente que é tanto constitutiva de um sujeito quanto de uma cultura.

Defendemos aqui que a memória, tal como concebida pela psicanálise, não se articula a conhecimento consciente, de forma que o inconsciente se realiza e produz seus efeitos, excluindo um saber consciente. Destarte, o recalque não constitui uma forma de esquecimento e, sim, uma memória que permanece viva e atuante, ainda que regulada pela paixão, pela ignorância, por um não querer saber fundamental.

Lacan (1959-1960/2008) ensina que o recalque não é um simples esquecimento, no sentido de afastar o representante da consciência, e, sim, um "esquecer que esqueceu", ou seja, o sujeito não tem acesso ao próprio mecanismo de rechaço da ideia inconsciente. O "esquecimento" oriundo do recalque é obra da compulsão de repetição, sendo motivado por um desejo inconsciente e não pelo mero fruto do acaso ou da impossibilidade natural em conservar todo o vivido.

Tal "esquecimento" indica o não reconhecimento, pela consciência, de uma representação e dos mecanismos que lhe concernem. Contudo, o recalque não é via de efetivo esquecimento; ao contrário, é via de perpetuação, de reatualização permanente da memória em seus substitutos e encobrimentos.

Assim, um sujeito ou um povo guardam a impressão de que o traço mnêmico, objeto de repúdio, desapareceu, e simplesmente não pensam mais no assunto, "esquecem" ou recordam dele como algo sem a menor importância. Mas essa aparência de tranquilidade é enganosa: a lembrança é preservada como um corpo estranho e goza do privilégio da "extraterritorialidade". Com isso, permanece inalterada e, ao mesmo tempo, prolifera em numerosas conexões, cujos ecos chegam à consciência como que amortecidos e incompreensíveis. Aquilo que foi excluído reaparece sob a forma de repetição, atualizando impulsos e fantasias que não estão no passado, mas no presente, manifestados de diferentes formas.

Para pensarmos a dinâmica dessa proposição freudiana no âmbito da memória, tomemos os efeitos do recalque na cultura, tendo como elemento de discussão o racismo. A cultura negra é constituinte de nossa 
memória social de tal forma que é impossível pensar o Brasil sem as raízes africanas. Contudo percebemos de forma bastante evidenciada as heranças de nosso passado segregacionista e escravocrata. Pensemos nessa relação de exclusão, concernente à operação de recalque - para posteriormente tomarmos a relação de incorporação, concernente à operação de luto - do negro em nossa cultura.

\section{O RACISMO, O BANZO E O BLUES: ARTICULAÇÕES COM O RECALQUE, A MELANCOLIA E O LUTO}

No dia 28 de agosto de 2014, jogavam pela Copa do Brasil, em Porto Alegre, Santos e Grêmio, quando o goleiro do Santos, Aranha, escutou os gritos dos torcedores gremistas que Ihe chamavam de "macaco". 0 goleiro procurou o árbitro e denunciou o fato. Em um país acostumado a encobrir o racismo, assim como as mais diversas práticas de exclusão das diferenças e das minorias, o fato não ocorreu sem as mais diversas repercussões. Trevisan (2014a), repórter do jornal virtual Ponte: segurança pública, justiça e direitos humanos, nos mostra que o Supremo Tribunal de Justiça Desportiva (STJD) tomou uma decisão histórica e inédita em toda trajetória do futebol mundial. No dia 03 de setembro, excluiu o Grêmio da Copa do Brasil por atos racistas de sua torcida contra o goleiro do Santos. Além disso, o clube foi multado e os torcedores proibidos de ingressar em jogos do Grêmio por 720 dias.

Os torcedores foram filmados e a imagem difundida repetidamente em rede nacional. Vimos uma torcedora branca, loira, que gritava "macaco", ser perseguida e ter sua casa queimada, dentre outras práticas que nos mostram que, longe de questionar nossa relação com as diferenças, centramos nosso ódio e nossa indignação em uma pessoa, como se a eliminação desse um colocasse fim à questão racial no Brasil. Assim como assistimos à prática de linchamento de estupradores, como se a morte de um indivíduo colocasse fim às práticas de submissão da mulher, quando, na verdade, apenas repete uma prática de violência e submissão do outro.

Aranha negou-se a participar do espetáculo midiático que pretendia promover um encontro entre o goleiro e a torcedora, e disse publicamente que queriam antecipar um perdão de alguém que nem sequer pediu desculpas; que, como pessoa, perdoava a torcedora, mas que não se encontraria com ela e que isso não a eximia do erro e de arcar com as penalidades legais concernentes ao seu ato. $O$ goleiro observou, ainda, que a questão está muito além da torcedora, pois, no Brasil, a cada dia ele sofre na pele a dor do racismo, relatando já ter sido até mesmo preso por estar com uma criança branca, acusado de sequestro sem qualquer indício de culpa, além da cor da sua pele. Com isso, o goleiro descentra a questão da imagem da torcedora e retoma o que há de cruel e, ao mesmo tempo, de encobrimento nas questões raciais no Brasil.

Contudo, os desdobramentos não param por aí. Tomemos fragmentos dos discursos sobre o fato ocorrido no jogo entre Grêmio e Santos, assim como sobre a própria questão racial: um de Pelé, rei do futebol brasileiro, e outro de Emicida (Leandro Roque de Oliveira), um dos grandes nomes do rap nacional.

Vale destacar que se trata de discursos perpassados por uma memória que é social e impregna a cada cidadão que nela se constitui, afetando o próprio modo como cada sujeito se reconhece e se posiciona. Mais do que condenar ou vangloriar o discurso de um homem, como percebemos nos discursos midiáticos, queremos ressaltar a memória como constitutiva de um discurso e de um povo. Longe de jogar a questão para debaixo do tapete, escamoteando-a, seja pelo ódio ou pela celebração do ato, é urgente observarmos os discursos que, ainda que negados, subjazem e geram efeitos de perpetuação da exclusão da diferença em uma cultura.

Em reportagem feita em 10 de setembro de 2014 por Baltar (2014) ao Globo Esporte, Pelé diz ser importante combater o racismo, mas condenou a atitude de Aranha ao reagir diante dos gritos de "macaco" vindos da arquibancada. Nas palavras do jogador:

O Aranha se precipitou em querer brigar com a torcida. Se eu fosse querer parar o jogo cada vez que me chamam de macaco ou crioulo, todos os jogos iriam parar. O torcedor grita mesmo. Temos que coibir o 
racismo. Mas não é num lugar público que você vai coibir. O Santos tinha Dorval, Coutinho, Pelé... todos negros. Éramos xingados de tudo quanto é nome. Não houve brigas porque não dávamos atenção. Quanto mais se fala, mas vai ter racismo. (PELÉ, 2014, apud BALTAR, 2014)

O racismo se faz no espaço público. Não é o racismo de um sujeito apenas, mas aquele que, criado e mantido no espaço público, nos constitui enquanto sujeitos, levando cada um de nós a lidar com nossas contingências e a criar nossas próprias estratégias para lidar com ele. Enquanto público, não pode ser coibido no espaço privado, não se trata de uma individualidade. Ou ele é discutido, inserido no espaço público, onde as memórias constituintes de um povo se presentificam e se refazem, ou terá efeitos de congelamento, no qual o conteúdo, relegado ao esquecimento, continua vivo, fazendo tempestuosas entradas na subjetividade, assim como no discurso e no laço social.

Perguntamo-nos: e se muitos jogos já tivessem, de fato, parado para se ouvir aquilo que vinha das arquibancadas, será que ainda teríamos que parar jogos hoje a partir do mesmo grito? Ou será que seria possível a invenção de um novo discurso e de um outro lugar para o negro e sua cultura no Brasil?

Não nos permitimos escutar a memória de nossa cultura e, com isso, ela retorna em ato com toda força e violência. Como Freud nos ensina, há uma resistência constituinte, um não querer saber, uma "política de avestruz" (FREUD, 1914a/2010, p. 203) que vira os olhos e os ouvidos a tudo aquilo que abala uma unidade imaginária, ilusória. E que, para ser mantida, gera dispêndio permanente de energia, pois, para permanecer em uma posição de passividade, certamente é necessária muita atividade, muito esforço para manter silenciado aquilo que urge e irrompe no tecido fino e inconsistente do discurso manifesto. Algo resta latente e, assim, ou escutamos suas irrupções, e decidimos produzir com elas, ou somos relegados ao lugar de expectadores inertes, que perpetuam o retorno dos mesmos traços.

O racismo e as atrocidades direcionadas ao negro no período escravocrata nunca foram de fato tocados. É como se a abolição da escravatura viesse acompanhada da abolição de todo um passado de crueldades e violência, e fosse possível seguir em frente, anulando um vivido que, recalcado, segue se presentificando por sintomas culturais. Os antigos locais de martírio do negro no Brasil, os pelourinhos, não são locais de vivificação dessa memória; o que é posto em cena é a beleza dos monumentos históricos, como se essa beleza não estivesse enraizada em milhares de mortes e açoites. Queremos destacar, com isso, que, quando falamos da negação do racismo em nossa cultura e de seus retornos como um efeito social correlato ao recalque, não se trata de um fenômeno novo, mas de um tabu imposto há décadas e que ainda vigora em nossos dias. Por essa perspectiva, mantemos uma imagem identificatória de acolhimento da diferença, imagem que se evidencia na ideia de que no Brasil não há racismo, e que o nosso processo de miscigenação acolhe todas as etnias e raças de forma igualitária, convivendo bem com a diversidade; contudo, o processo está calcado na abolição das diferenças. 0 discurso que sustenta "que todos somos iguais" nega as diferenças oriundas de nossa própria constituição cultural, e, ao dissolver a diversidade, mantém camuflados os preconceitos, o ódio e o racismo direcionados a alguns grupos e etnias presentes em nossa cultura.

"Tirar a cabeça do buraco", ou do jogo, no caso de Pelé, pode trazer efeitos não apenas subjetivos, mas no próprio jogo de forças no qual a memória de uma cultura nos lança. Colocar a "mão no barro", ou nos significantes que nos são inerentes, ainda que nos pareça sujo e repugnante, pode trazer efeitos de criação, de invenção, para o surgimento de algo novo, até então inédito no modo como um povo pode se constituir. Efeitos de inserir no tecido de uma cultura tudo aquilo a geriu, deixando que, no imbricamento, se fecundem e se transformem.

Pensemos agora no discurso de Emicida, falando sobre o mesmo evento, porém ampliando sua fala para a própria lógica do racismo, que subjaz a esse ato que nada tem de isolado. Assistindo ao jogo, Emicida percebeu que, de repente, os comentadores param de falar do futebol e começam a falar de racismo. Aqui já pensamos que o ato de Aranha de ouvir, e não de negar, o que vem das arquibancadas possibilita um ato 
inédito no país do futebol. Ele faz com que todos os brasileiros desloquem seu olhar da bola para escutar e pensar sobre algo bastante camuflado e silenciado: o modo como nos apropriamos de nossa história e construímos memórias que nos perpassam e constituem, colocando uma diferença radical entre negros e brancos, ainda que dividam o mesmo espaço público, a mesma bola, a mesma paixão pelo futebol.

Não há como se posicionar diante dessa diferença se negamos sua existência. Lembrando que a negação é um importante mecanismo de defesa, através do qual, nesse caso, recusamos a entrada no discurso social de algo que nele se afirma, ou seja, a afirmação permanece latente, como uma poeira lançada embaixo do tapete, que teima em aparecer, e que nunca poderá ganhar novo destino, se não a encaramos abertamente.

Emicida prossegue: "o racismo é um crime bizarro no Brasil, acontece com uma frequência monstruosa e nunca ouvi falar de alguém que tenha sido realmente condenado pelo crime de racismo" (TREVISAN, 2014b). O rapper lembra que, quando criança, as professoras da escola olhavam a cabeça dos alunos para ver se tinham piolho, porém "não tocava os preto não. A gente não entende isso". Com isso, Emicida nos diz que uma criança negra sente vergonha da cor da sua pele, se sente errada, feia, sente-se menos, esforçando-se o resto da vida para permanecer invisível, "quer se tornar invisível para não ser discriminada" (idem).

Ele não consegue se lembrar da primeira vez que sofreu racismo, pois "você não entende o racismo no começo. Na infância você não entende o racismo [...] você começa a dialogar sobre o racismo na adolescência, 16 anos, 15 anos, mas a gente sofre ele desde pequeno" (idem). Assim, para ele, o racismo deve ser trabalhado dentro da escola, no espaço público onde se apresenta. Aprovar estatutos em defesa da causa negra é importante, "mas a partir do momento em que as pessoas negam o problema, elas não têm como combater com seriedade, e é isso que acontece no Brasil" (idem).

É frequente escutarmos "no Brasil não tem racismo", ao lado de ditos populares como: "negro, quando não caga na entrada, borra na saída", "preto e burro, é porrete e murro", "você está fazendo serviço de preto" - em referência a um trabalho mal feito -, "é um preto de alma branca", dentre muitos outros. Ditos populares que revelam o que está latente na memória constitutiva de nossa cultura: as heranças do período escravocrata ainda se perpetuam.

Quais são os efeitos da negação do racismo? Seu retorno em ato, pela violência diária a que é submetido um sujeito desde seu nascimento, pelas mais diversas vias simbólicas - e com as quais ele se constitui e se reconhece, assim como pelo ataque direto ao seu corpo e à sua vida.

Foi lançado em 2014, pela Secretaria-Geral da Presidência da República e pela Secretaria Nacional de Juventude, o documento O mapa da violência: os jovens do Brasil. O documento, de autoria de Júlio Jacobo Waiselfisz, sociólogo e coordenador de inúmeras pesquisas sobre violência no Brasil e na América Latina, nos mostra como a mitologia da democracia racial encobre a realidade segregacionista e discriminadora, em que se evidencia que o racismo mata, sendo a cor da pele importantíssima para pensarmos os índices de mortalidade no Brasil.

Trevisan (2014c) ressalva que, em 2012, houve no país 56 mil homicídios, sendo 41.127 vítimas negras. São 154 vítimas diárias, 1,4 massacres do Carandiru por dia. A falta de visibilidade conferida aos homicídios, tratados com indiferença e naturalização, parece se articular com o fato de que a maior parte das vítimas é negra e moradora de favelas, evidenciando ainda mais o racismo no país, pois, se os homicídios tivessem outro perfil, jovens brancos e de classe média a alta, possivelmente já teríamos exigido uma resposta das autoridades e o governo já teria criado diversas políticas e campanhas de combate à violência.

Tal esquema opera pela culpabilização da vítima, justificando a violência dirigida, principalmente, a setores subalternos ou particularmente vulneráveis que demandam proteção específica, como mulheres, crianças e adolescentes, idosos, negros etc. Os mecanismos dessa culpabilização são variados: a estuprada foi quem provocou, pois, por exemplo, ela se vestia como uma "vadia"; o adolescente vira marginal, delinquente, drogado, traficante; aceitabilidade de castigos físicos ou punições morais com função "disciplinadora" por parte das famílias ou instituições; moreno de boné e bermudão é automaticamente suspeito etc. 
A própria existência de leis ou mecanismos específicos de proteção - estatutos da criança, do adolescente, do idoso; Lei Maria da Penha; ações afirmativas etc. - indicam claramente as desigualdades e as vulnerabilidades existentes, sem, contudo, colocar efetivamente em questão todo o jogo de forças que se presentifica.

Ao negar a violência, muitas vezes dirigidas a grupos bastante específicos, seus efeitos são neutralizados e perpetuados. Recusamos uma entrada efetiva no discurso social daquilo que já é parte constituinte dele, que faz parte de sua memória. Relegamos ao "esquecimento", próprio do recalque, aquele em que o conteúdo repelido "prolifera no escuro" (FREUD, 1915/2010), produzindo diversos efeitos, ainda que no desconhecimento, produzindo uma memória em ato, na qual um sujeito ou uma cultura não se reconhece, mas estranha, repudia. Contudo, operar com a diferença convoca a criação, pois produz um furo nos recursos identificatórios utilizados até então. Implica necessariamente em uma dimensão de perda, que possibilita o novo.

Lacan ensina que "nos textos de Freud, repetição não é reprodução. Jamais houve qualquer oscilação sobre esse ponto - Wierderholen não é Reproduzieren" (LACAN, 1964/1998, p. 52). Freud aponta uma presentificação do passado em ato, porém um ato não é um comportamento, um ato implica um sujeito, e cabe a questão: como eu consegui fazer a mesma coisa? Pagar o mesmo custo? A repetição é uma repetição atuada, querida, refeita, reinvestida, não é acidental, não é comportamental.

Os elementos da cadeia significante se repetem. Não é uma cadeia variada, é uma cadeia que se repete de inúmeras formas, de modo que "é a estrutura mesma da rede que implica os retornos" (ibidem, p. 69). Tomando um sujeito que nasceu em um determinado código linguístico, em uma determinada cultura, imerso por uma determinada memória, vemos como os significantes que lhe fundam e constituem são limitados. Em uma cultura, temos uma cadeia cujas pontuações e articulações significantes variam, mas sempre retornam aos mesmos elementos do código. É da rede que emerge que eu possa me contar, e isso vai se repetir, comparecer de novo, porém não igualmente. Repetir-se, contudo, sem ser o mesmo; possibilidade para que, sem nenhuma garantia, se funde um outro lugar, uma outra posição.

Lacan nos fala da repetição sob dois prismas: Tiquê e autômaton. Tiquê, termo tomado do vocabulário de Aristóteles, que designa "encontro do real. O real está para além do autômaton, do retorno, da volta, da insistência dos signos" (LACAN, 1964/1998, p. 56). O real como encontro, o encontro enquanto podendo faltar, "essencialmente é encontro faltoso" (ibidem, p. 57).

Repetição não é reprodução, nem rememoração agida: "o que se repete [...] é sempre algo que se produz - [...] - como por acaso" (LACAN, 1964/1998). Algo na experiência desperta um traço de memória inesperado que pode se articular com o vivido, colocando a cadeia significante em movimento, mas os significantes já partem de uma posição que não é a mesma de outrora. E, se há a insistência dos signos, indicada por autômaton, há antes uma repetição que atualiza um encontro faltoso, que se articula com a própria possibilidade de um des-encontro criador, que possa relançar a algo de novo. Donde tomamos o trabalho de luto como possibilidade de invenção a partir dos significantes que nos constituem.

Freud (1917[1915]/2011) ensina que o luto é a reação à perda de uma pessoa querida ou de uma abstração que esteja no lugar dela, como pátria, liberdade, ideal etc. É, portanto, uma reação possível à perda de um objeto, sobre o qual há um grande investimento de energia. $O$ termo objeto se refere a qualquer elemento da realidade externa, psíquica ou do próprio corpo no qual se deposite um investimento. Assim, o objeto pode ser uma pessoa, uma ideologia ou uma imagem, dentre infinitas possibilidades.

Conforme Freud, "se o objeto não tiver para o eu um significado tão grande, reforçado por milhares de laços, sua perda não se prestará a provocar um luto" (FREUD, 1917[1915]/2011, p. 80-81). Destarte, um objeto só adquire grande importância se está ligado a uma série de traços de memória, de forma que sua perda coloca em movimento diversos investimentos e encadeamentos psíquicos, colocando em questão a existência e a sobrevivência do próprio sujeito. Há no luto, portanto, a exigência de um reordenamento da memória. 
Não obstante, a aderência aos objetos de investimento é uma fixação que não é abandonada de bom grado, de forma que o luto não é consequência inevitável à perda de um objeto. Diante de uma perda, condição traumática por excelência, pode-se erguer um muro de silêncio, um tabu subjetivo ou social, construído mediante operações de recalcamento e censura, de repúdio à realidade psíquica e à realidade histórica, o que não pode ser sem consequências. Nesse caso, o recalcado aparece por seus derivados, e o resultado do processo não seria o esquecimento e a possibilidade de novos investimentos, mas, sim, uma fixação, donde o recalcado proliferaria, deixando seus efeitos sintomáticos de repetição em ato, na tentativa de atualizar o já vivido, atualizando o objeto perdido.

Não é possível, portanto, desapaixonar, como destraumatizar, em uma "depuração benéfica das escórias emotivas" (MEZAN, 1989, p. 73). Ao contrário, esse é um procedimento por excelência defensivo. Não é à toa que Freud nos afirma com veemência que um trabalho de luto não é possível sem dor: não se neutraliza o objeto e se livra da dor; é preciso se fazer com ela e apesar dela.

Portanto, o luto se produz não quando o sujeito consegue desfazer-se de um objeto ausente na realidade, para poder acolher outro, mas, sim, quando o próprio sujeito se torna outro, efetuando essa perda irremediável, irrecuperável de parte de si, sem a qual não é possível seguir sendo o mesmo. O luto implica em dessubjetivação. Segundo Maurano (2001), no luto, o sujeito perde um objeto que funcionava como seu suporte, um objeto que the oferecia coordenadas simbólicas a partir das quais ele se referenciava. A impotência em recuperar o objeto, experimentada no luto, subverte a referência através da qual o sujeito ancorava sua subjetividade e abrigava uma esperança de consistência. Daí o caráter perturbador do luto.

O Eu permanece vivo, todavia não igual, pois vigora nele uma série de traços do objeto perdido. Logo, se a vivência do luto comporta Eu me identificar aos traços do objeto, implica que Eu (referindo-se a uma subjetividade ou a uma cultura) me faço outro pelos traços desse objeto que eu acolho - dimensão de invenção presente em toda perda, que conduz a uma celebração da vida.

Freud, no texto já mencionado Luto e melancolia (1917[1915]/2011), esclarece dois destinos possíveis diante da perda de um objeto: o luto e a melancolia. Nessa última, não ocorre essa separação entre sujeito e objeto, o sujeito sabe que perdeu um objeto de amor, mas não consegue reconhecer o que foi perdido junto com ele, ou seja, as coordenadas identificatórias que o ligavam ao objeto não podem ser reconhecidas e o lugar do objeto não advém como vazio. Nas palavras de Freud no texto aqui citado: "a sombra do objeto caiu sobre o eu (...). Assim, a perda do objeto se transformou em perda do eu" (FREUD, 1917[1915]/2011, p. 61). $\mathrm{O} \mathrm{Eu}$, ligado de forma maciça e indissociável ao objeto, sente-se aniquilado junto com ele e um contorno simbólico ao vazio não pode ser estabelecido.

No texto Introdução ao narcisismo (1914b/2010), Freud aponta uma importante via para pensarmos o processo de identificação concernente à melancolia. Ele aproxima a identificação à incorporação canibalística, em que o eu incorpora traços dos objetos amados e, então, ele se torna esses traços, fazendo-se inseparável deles.

Buscando evidenciar essas duas operações possíveis diante da dor experimentada perante a perda de um objeto, destacamos, ainda a partir da cultura negra, dois fenômenos culturais bastantes conhecidos: o banzo - melancolia que acometia muitos negros africanos tirados de suas tribos e de seu país para o regime escravocrata - e o surgimento do blues na sociedade estadunidense.

Oda evoca as memórias de Luis Antonio de Oliveira Mendes - baiano que, nascido em 1750, formou-se em leis na Universidade de Coimbra, tendo estreito contato com os negros africanos submetidos à escravidão ao retornar a sua terra natal - escritas em 1793, sobre as enfermidades dos negros cativos nas diversas etapas do comércio de escravos. Ele nos diz que uma das principais moléstias crônicas de que sofriam os escravos, e que, pelo decurso do tempo, os levavam à sepultura, é o banzo, definido como uma "paixão da alma" que atingia os africanos escravizados, um intenso ressentimento que poderia ser causado por saudades da terra 
natal, por amores perdidos, injustiças e traições sofridas e, principalmente, pela "cogitação profunda sobre a perda da liberdade" (ODA, 2012).

A moléstia se manifestava desde a travessia atlântica ou logo depois da chegada ao Brasil, descrita como uma espécie de suicídio passivo: o indivíduo parecia triste e apático, ficava imóvel e calado, recusava todo alimento, definhava e deixava-se morrer. Rubim de Pinho, psiquiatra que pesquisou doenças mentais em sua relação com a cultura, lembra que a vocação para a tristeza era de fato própria aos negros importados da África: "A partir da viagem até a chegada às nossas costas, [os africanos] apresentavam estados de definhamento, ficavam parados, e a própria expressão Banzo, suposta de procedência angolana, reflete seguramente uma nostalgia, uma saudade da terra” (DE PINHO, 1982, p. 20). E assim descreve o banzo: “[...] como um tipo de nostalgia ou melancolia mortal dos negros da África, se tomados cativos e ausentes de suas pátrias. O antecedente do africanismo 'banzar' é encontrado [...] no verbo cubanza, de língua angolana, significativo de 'pensar'” (DE PINHO, 1982, p. 20), sendo muitas vezes identificado a estar pensativo, gerando tristeza, e perplexidade.

O banzo era um fenômeno tão recorrente entre os negros africanos trazidos forçosamente ao Brasil que ganhou uma nomeação para representá-lo, sendo por vezes identificado a uma prática comum de resistência à escravidão, a uma forma de protesto pela greve de fome, à prática do suicídio, do aborto, do infanticídio; enfim, marcado por práticas nas quais o sujeito se retirava de forma consentida da vida e/ou tirava a vida dos seus.

O banzo, como um fenômeno social, evidencia a reação melancólica de um povo à perda de sua pátria, seus costumes, sua liberdade; enfim, aos seus laços amorosos e identificatórios. A perda é tão radical que é impossível a esse povo elaborá-la, fazer contornos simbólicos que permitam a eles lidar com o vazio. Não há recurso simbólico que venha em socorro, o sujeito e seus laços amorosos são tornados um só e a morte desses laços equivale à morte do próprio sujeito, evidenciando a impossibilidade do luto.

Em contrapartida a essa lida com a perda, pensemos a criação do blues pelos negros levados aos Estados Unidos para o trabalho escravo. Em 1619, os negros já começavam a ser trazidos aos Estados Unidos como mão de obra escrava. Poucas décadas depois, já estão presentes em praticamente todas as colônias, como prática institucionalizada. Eles são levados especialmente para os campos de algodão e tabaco no sul do país e, além de todo o sofrimento, oriundo do fato de serem arrancados de sua pátria, separados de suas famílias e do trabalho e dos castigos forçados, é proibido todo tipo de manifestação cultural, elemento que parece ter grande importância para a invenção do blues.

Diante da estratégia dos brancos em abolir os instrumentos de menção africana, os escravos negros estabeleceram táticas que subvertiam a lógica do dominador, tocando seus instrumentos de maneira distorcida, ou seja, uma vez privados de tocar seus próprios instrumentos, os negros norte-americanos passariam a utilizar os instrumentos de seus senhores, porém, utilizando-os à sua maneira e recorrendo, por exemplo, à adoção de um esquema antifonal de cântico, típico das sociedades africanas.

Privados do lazer, a musicalidade encontrou o seu espaço em um dos únicos ambientes de convivência coletiva: o trabalho. Durante a lida no campo, canções eram entoadas para cadenciar o seu ritmo ou simplesmente para amenizá-la, tornando-a menos dolorosa e sofrível aos negros africanos. Enquanto uma voz entoava um verso, o coro era feito pelos outros trabalhadores. Inicialmente eram entoadas em línguas africanas pertencentes aos macrogrupos étnico-linguísticos. Posteriormente, devido à convivência com os fazendeiros e seus funcionários, ocorreu uma mescla com palavras em inglês. Uma manifestação quase primitiva, mas extremamente sentimental e sempre rítmica (PINHEIRO; MACIEL, 2011). A voz se apresentava como o único e principal instrumento musical do negro e meio de expressão e sustentação de suas tradições.

Existem outras interpretações e hipóteses quanto à origem do blues. Para alguns pesquisadores, ao invés das plantações, seria no espaço das manifestações religiosas que encontraríamos decisivamente a composição do mesmo. No século XIX, com a chegada de verdadeiras levas humanas oriundas da África, a evangelização 
foi um dos meios, senão o principal, de introdução à "cultura branca" por parte dos americanos, e, no universo religioso que thes era imposto, foram introduzindo sua cultura e sua musicalidade. Contudo, muitas canções religiosas evoluíram a partir dos gritos musicados nos campos do sul.

O blues começou a ser reconhecido e utilizado comercialmente a partir do êxodo rural que se sucedeu à crise de 1929 e à queda da bolsa de valores de Nova York. Nesse momento, muitos negros migraram para os grandes centros urbanos, sendo marginalizados em guetos marcados pela pobreza e pela exclusão social. Ali se reuniam em galpões, para cantar sua tristeza e seus amores. As letras de blues discursavam, particularmente, sobre a descrença social, anunciavam as angústias do trabalho estafante, do viver à margem da sociedade, do ter que se contentar com a miséria e vivenciar o preconceito. Assim, o blues nasce como resposta às segregações sofridas e igualmente como uma manifestação cultural própria, necessária no cotidiano de toda sociedade. Como retrata Muggiati (1995, p. 14), "misturando o seu grito primal com as canções de trabalho e com as canções de ninar, com a harmonia dos hinos religiosos e com a estrutura das baladas, o negro americano chegou ao blues, sua principal forma de expressão". Importante tática criada pelos negros como uma forma de resistência e expressão de sua dor e sua cultura.

O blues é fruto de um trabalho de luto. Tal manifestação tem o cunho de uma memória cultural que prima por se apresentar como efeito de um luto bem sucedido frente às perdas e privações decorrentes da memória traumática da escravidão.O blues faz ressoar o objeto perdido, compondo-o com ritmo, melodia, tons... Há um reconhecimento da dor, aliado a uma possibilidade de fazer algo com ela para a continuidade da vida.

Algo até então inédito surge como efeito da assimilação de traços do objeto perdido. As memórias referentes à terra de origem não permanecem na eterna ruminação, o que promoveria um retorno incessante do ressentimento e uma sacralização do passado. Longe disso, as memórias foram digeridas, inseridas no tecido da vida, assimiladas, sendo indissociáveis daquele povo.

Diante da perda de seus laços amorosos, decorrentes do regime escravocrata, o povo negro consegue lançar mãos de traços do objeto perdido, traços atualizados pela voz, pela sonoridade própria ao seu povo, e reinventar-se a partir deles. Invenção que não passa pelo recalque, mas pela possibilidade de acolher em si os precipitados do objeto perdido e contornar o lugar deixado vazio, parindo-se a partir do corte, de uma fratura violenta e radical que coloca em causa o próprio sujeito.

Eis a dimensão da repetição apontada por tiquê, que mencionamos anteriormente, a qual em nada se relaciona com o eterno retorno do mesmo, mas, sim, com as possibilidades germinativas de um passado, uma história aberta, e sempre relançada de modo inacabado. Não se trata de uma repetição automática autômaton - que apenas reitera infinitamente o ressentimento e a dor. Tiquê convoca à criação e a uma criação que, ancorada no Outro, só pode se dar de forma inédita, de modo que cada sujeito, cada cultura, pode inventar para si. Construção singular e plural ao mesmo tempo, que pode ser efeito do luto.

\section{CONSIDERAÇÕES FINAIS}

O luto implica, portanto, em um trabalho de incorporação e reordenamento dos traços mnêmicos constituintes de um sujeito, um povo, uma cultura. Deixar morrer implica em continuar vivendo, acolhendo em si os traços do morto que nos habita, sem relegá-los ao desaparecimento do recalque que é via de perpetuação e não de esquecimento e criação. O luto implica em uma reinvenção de si a partir dos traços do objeto que me eram caros, preciosos, tanto que não posso e não quero deixá-lo para traz.

Branco ressalva que, ao fim do trabalho de luto, um contorno simbólico pode ser construído para a perda, "desvinculando o lugar da perda e o objeto perdido" (BRANCO, 2013, p. 74), ou seja, o objeto morto aparece para o enlutado como o objeto do desejo e logo the sucede que, junto com o objeto, morre a própria possibilidade de desejar. Contudo, o desejo se articula à falta, a das Ding, e não a um objeto específico. 
O luto promove um esvaziamento desse lugar antes imaginariamente ocupado pelos laços de amor que nos ligavam a um objeto, descolando-o de uma posição de fixidez e logo criando a possibilidade de retornar a ligação da libido com o mundo e de estabelecer uma nova eleição de objeto. O lugar vazio do objeto torna-se fonte de novas possibilidades de laços objetais, promovendo uma separação entre o objeto e o si mesmo, entre o lugar simbólico que ele ocupava e o Eu, de forma que nos tornamos capazes de consentir a perda que o fim dos laços com o objeto causa em nossa própria imagem, produzindo inevitavelmente um furo identificatório.

Ao produzir um furo identificatório, o luto convoca o sujeito a se reposicionar diante do Outro e de sua própria falta, pois o objeto em jogo no luto funcionava como suporte de nossa falta. Desse modo, por trás do amor objetal, figura a falta de objeto que nos é constituinte.

Donde podemos depreender que, sendo a ausência de objeto o suporte e origem do laço social, e do próprio sujeito, advir como cultura e como sujeito implica em um processo de luto, em promover um contorno simbólico ao vazio; contorno que é o próprio fundamento e materialidade do laço social e do sujeito. Os contornos simbólicos admitem e promovem uma outra lida com a falta. Possibilitam fazer dela lugar de jogo, de troca, de intercâmbio, de produção de sentidos e laços.

Esse contorno implica na própria possibilidade de subjetivação, já que, como resultado dele, incorporamos traços dos objetos perdidos, pelos quais podemos nos reconhecer e nos referenciar, de forma que o destino do objeto - e, portanto, o luto - provocará efeitos diretos sobre a identificação. Os laços que permaneciam ligados ao objeto se rompem, para serem incorporados no próprio sujeito, permitindo, assim, que os traços do objeto façam parte do Eu e que o objeto possa ser substituído. Afinal, todo objeto é mesmo sempre substitutivo de das Ding.

Ao mesmo tempo, o luto possibilita a sustentação do desejo, malgrado qualquer objeto, já que o desejo se liga ao vazio fundamental que sustenta e põe em circulação o próprio desejo. Ao retirar a libido do objeto, o luto faz a manutenção da ligação do sujeito com o vazio em que o desejo está sustentado. E, mais do que isso: o processo de luto reatualiza simbolicamente a perda original que funda o próprio objeto como faltoso.

Somente pelo acolhimento da falta, e pela possibilidade de uma nova tessitura, é que o evento psíquico pode ser reconhecido como passado; pode ser esquecido, fazendo parte de uma realidade histórica. Tal acontecimento pode ser lembrado e não repetido no presente. Em análise, constituímos um passado, no sentido literal da palavra, que não mais se atualiza e faz do presente uma extensão do que não passou. No âmbito social, várias estratégias de interdição e de tabu conferem a uma experiência os efeitos de recalque, e, assim, o que permanece como interdito perpetua suas raízes na experiência, ou seja, o interdito retorna em ato. Havendo um interdito, há a negação de algo que se afirma, e, logo, há a impossibilidade de deixar que a experiência germine o futuro, produzindo seus efeitos, efeitos de criação, pelos quais uma cultura e um povo podem não ser mais os mesmos, deixando advir um desejo novo.

Recebido: 28 de setembro de 2015. Aprovado: 3 de março de 2016.

\section{Referências}

BALTAR, M. 2014. Disponível em: <http://globoesporte.globo.com/futebol/selecaobrasileira/noticia/2014/09/pele-sobre-participacao-brasileira-na-copa-do-mundo-umdesastre.html>. Acesso em: 08 set. 2014.

BRANCO, F. de O. C. O espaço, a linguagem e a morte: sobre a melancolia em psicanálise. Tese de doutorado defendida no Programa de Pós-graduação em Psicanálise da UERJ. Dez. 2013. (Texto inédito).

DE PINHO, R. Aspectos históricos da psiquiatria folclórica no Brasil. Universitas, v. 0, n. $29,1982$. Disponível em: <http://www.portalseer.ufba.br/index.php/universitas/article/view/1263/846>. Acesso em: 22 jul. 2014

FREUD, S. A interpretação dos Sonhos (1900). Trad. Renato Zwick. Porto Alegre: L\&PM, 2012. 
. A repressão (1915) Trad. e notas Paulo César Souza. São Paulo: Companhia das Letras, 2010. (Obras completas, 12).

. Introdução ao narcisismo (1914b) Trad. e notas Paulo César Souza. São Paulo: Companhia das Letras, 2010. (Obras completas, 10).

Luto e Melancolia (1917[1915]). Trad. Marilene Corone. São Paulo: Cosac Naify, 2011.

O inquietante (1919) Trad. e notas Paulo César Souza. São Paulo: Companhia das Letras, 2010. (Obras completas, 14).

Recordar, repetir e elaborar (1914a) Trad. e notas Paulo César Souza. São Paulo: Companhia das Letras, 2010. (Obras completas, 10).

LACAN, J. A ética da psicanálise (1959-1960). Rio de Janeiro: Jorge Zahar, 2008. (O seminário, 7).

Os quatro conceitos fundamentais da psicanálise (1964). Rio de Janeiro: Jorge Zahar, 1998. (O seminário, 11).

MAURANO, D. A face oculta do amor: a tragédia à luz da psicanálise. Rio de Janeiro: Editora UFJF, 2001.

MEZAN. R. Esquecer? Não, in-quecer? In: FERNANDES, H. (org.). O tempo do desejo: psicanálise e sociologia. São Paulo: Brasiliense, 1989.

MUGGIATI, R. Blues: da lama à fama. Rio de Janeiro: Editora 34, 1995.

ODA, A. M. G. R. O banzo: mal do tráfico transatlântico de escravos. Revista pré-Univesp: Escravidão. n. 24, set. 2012. Disponível em: <http://www.univesp.ensinosuperior.sp.gov.br/preunivesp/3898/obanzo-mal-do-tr-fico-transatl-ntico-de-escravos.html>. Acesso em: 15 maio 2014.

PINHEIRO, M.; MACIEL, F. Blues: manifestação e inserção sociocultural do negro no início do século XX. Revista Outros Tempos: dossiê da história atlântica e da diáspora africana. v. 8, n. 12, dez. 2011, p. 221-238. Disponível

em:

<http://www.outrostempos.uema.br/OJS/index.php/outros_tempos_uema/article/view/61/48]>. Acesso em: 18 maio 2014.

TREVISAN, M. C. O racismo que mata. 2014c. Disponível em: <http://ponte.org/o-racismo-quemata/>. Acesso em: 24 out. 2014.

Punição ao Grêmio é histórica, mas não basta. 2014a. Disponível em:

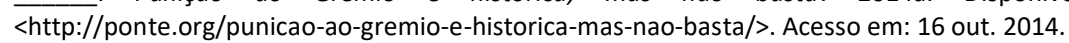

Quando você chama a pessoa de macaco, você está jogando toda a humanidade dela no lixo. 2014b. Disponível em: <http://ponte.org/quando-voce-chama-a-pessoa-de-macaco-voce-estajogando-toda-a-humanidade-dela-no-lixo/>. Acesso em: 12 set. 2018.

Nilda Martins Sirelli

nildasirelli@yahoo.com.br

Denise Maurano

dmaurano@corpofreudiano.com.br 